\title{
Physiological Responses of Calystegia soldanella under Drought Stress
}

\author{
Chae-Youn Bae ${ }^{1 \dagger}$, Jeong-Sook Hwang ${ }^{1 \dagger}$, Jeong-Jin $\mathrm{Bae}^{2}$, Sung-Chul Choi ${ }^{1}$, Sung-Hwan Lim ${ }^{1}$, \\ Deok-Gyun Choi ${ }^{1}$, Jong-Guk Kim ${ }^{3}$ and Yeon-Sik $\mathrm{Choo}^{1, *}$ \\ ${ }^{1}$ Department of Biology, Kyungpook National University, Daegu 702-701, Korea \\ ${ }^{2}$ National Institute of Ecology Incorporation Planning Office, Ministry of Environment, Seocheon 325-813, Korea \\ ${ }^{3}$ Department of Life Sciences and Biotechnology, Kyungpook National University, Daegu 702-701, Korea
}

\begin{abstract}
This study was conducted to determine the extent of drought resistance based on physiological responses of Calystegia soldanella under water deficit. In order to investigate the changes of plant growth, stomatal density, photosynthesis, chlorophyll fluorescence, the contents of chlorophyll and carotenoid, osmolality, total ion contents, the contents of carbohydrate and proline, C. soldanella was grown under well watered and drought stressed conditions for 12 days. In this study, water-deficit resulted in remarkable growth inhibition of $C$. soldanella. The effect of water-deficit on plant growth was associated with low osmotic potential of soil. On day 12 after drought treatment, dry weight, relative water contents, number and area of leaves and stem length were lower than those of control. The stomatal conductance and net photosynthetic rate were significantly reduced in water stressed plant to regulate inner water contents and $\mathrm{CO}_{2}$ exchange through the stomatal pore. Chlorophyll fluorescence and chlorophyll contents were not different in comparison with the control, indicating that the efficiency of photosystem II was not affected by drought stress. This results could be explained that water-deficit in C. soldanella limits the photosynthetic rate and reduces the plant's ability to convert energy to biomass. A significant increase in total ion contents and osmolality was observed on day 7 and day 12. Accumulation of proline in leaves is associated with the osmotic adjustment in C. soldanella to soil water-deficit. Consequently, this increase in osmolality in water stressed plant can be a result in the increase of ion contents and proline.
\end{abstract}

Key words: Coastal sand dune plant, chlorophyll fluorescence, photosynthesis, proline, water stress

\section{INTRODUCTION}

Plant species on coastal sand dune areas are affected by many environmental stresses that negatively impact plant metabolism and survival. Drought, salt spray, flood, high temperature, low capillary water-holding capacity of the sandy soil, low nutrient and water availability are the important ecological factors (Hesp 1991, Maun 1998, Lawlor and Cornic 2002). In coastal sand dune regions, water-deficit stress is one of the major stresses. The fre- quent moisture deficiency caused by high evaporative demand limits plant growth, development and viability. General adverse effects of water deficit on plants are the decline in height and total fresh and dry biomass production (Baher et al. 2002, Farooq et al. 2009). Plant growth is largely affected by drought stress, and therefore adaptation on stress conditions is important for plant survival. The reduction of plant height is related to the decrease http://dx.doi.org/10.5141/ecoenv.2013.255

(c) $\begin{aligned} & \text { This is an Open Access article distributed under the terms of } \\ & \text { the Creative Commons Attribution Non-Commercial Licens } \\ & \text { (http://creativecommons.org/licenses/by-nc/3.0/) which }\end{aligned}$
permits unrestricted non-commercial use, distribution, and reproduction in any
medium, provided the original work is properly cited.
Received 08 November 2013, Accepted 26 November 2013

*Corresponding Author

E-mail: yschoo@knu.ac.kr

Tel: +82-53-950-5346

${ }^{\dagger}$ These authors contributed equally to this work. 
in the cell enlargement and cell expansion due to the low turgor pressure (Bhatt and Srinivasa Rao 2005, Jaleel et al. 2007, Karthikeyan et al. 2007).

Many plants respond to water stress at the physiological and biochemical levels. Water stress is characterized by traits like decreased water and turgor potentials, relative water content (RWC), osmotic adjustment, wilting, high leaf temperature, closure of stomata, and decrease in cell enlargement and growth (Kumar and Singh 1998, Paseban-Islam et al. 2000, Shao et al. 2008). Stress as a result of water deficit changes a range of physiological processes such as photosynthesis, respiration, transpiration, ion uptake, carbohydrate contents, stomatal conductance and electron transport (Acevedo et al. 1971, Angelopoulos et al. 1996, Flexas et al. 1998, Lu and Zhang 1998, Clifton-Brown et al. 2002, Munns 2002, Silva et al. 2007). Under drought stress, to avoid and tolerate stress conditions plants accumulate metabolies as osmolytes (Bartels and Sunkar 2005). Particularly, proline has been suggested to play an important role as an organic osmolyte. Many studies have shown that proline contents in leaves of many plants are increased by many stresses including drought stress (De Ronde et al. 2000, Abdel-Nasser and Abdel-Aal 2002, Parida et al. 2002).

Understanding of the physiological mechanisms of many stressors is important in predicting how disturbances will impact future plant distribution and community pattern. Previous studies have suggested that adaptive features of coastal dune plants include tolerance to high temperatures, and efficient water use under high water-vapor saturation deficit (Monson et al. 1983, Mooney et al. 1983).

Calystegia soldanella is an endemic plant on coastal sand dunes and is located in the foredunes where environmental stresses are stronger. This plant is a perennial rhizomatous herb with stem up to $50-100 \mathrm{~cm}$, and is a representative plant showing ubiquitous distribution on coastal sand dune in Korea. Many wild plants have a tolerance to water stress, but its extent varies from species to species. It is well known that how plants cope with many environmental stresses, but the effect of the drought stress on C. soldanella plant has not been studied well. The object of this study is to determine the extent of drought resistance based on physiological responses under water deficit.

\section{MATERIALS AND METHODS}

\section{Plant Material and Growth Conditions}

The seeds of $C$. soldanella were collected from the Golaebul sand dune on the eastern coast in Korea $\left(36^{\circ} 14^{\prime} 90^{\prime \prime} \mathrm{N}, 129^{\circ} 22^{\prime} 50^{\prime \prime} \mathrm{E}\right)$ in June 2010 . C. soldanella was soaked in $98 \%$ sulfuric acid for two and a half hours and then washing out repeatedly. Finally, these seeds were soaked in distilled water for $30 \mathrm{~min}$. Selected seeds were germinated separately in a pot $(11 \mathrm{~cm} \times 9 \mathrm{~cm})$ filled with sand soil. The soil medium used was originally taken from the Golaebul sand dune. This experiments were conducted in the Kyungpook National University, from August to September 2011 in greenhouse where mean temperatures was about $27^{\circ} \mathrm{C}$ and relative humidity was about $30 \%$. Natural light from the sun with a mean daytime photosynthetic photon flux density (PPFD) was $460 \mu \mathrm{mol}$ $\mathrm{m}^{-2} \mathrm{~s}^{-1}$. After sowing, every pot received modified Hoagland's solution $\left(0.5 \mathrm{mM} \mathrm{NH}_{4} \mathrm{NO}_{3}, 0.5 \mathrm{mM} \mathrm{MgSO}_{4} \cdot 7 \mathrm{H}_{2} \mathrm{O}\right.$, $0.5 \mathrm{mM} \mathrm{KH}{ }_{2} \mathrm{PO}_{4}, 0.5 \mathrm{mM} \mathrm{CaCl}_{2} \cdot 2 \mathrm{H}_{2} \mathrm{O}, 0.5 \mathrm{mM} \mathrm{K}_{2} \mathrm{SO}_{4}, 19$ $\mathrm{mM}$ Fe-EDTA and trace elements) every day with $100 \mathrm{~mL}$ for 3 weeks. The experiment was composed of two irrigation treatments (well-watered and drought conditions). The experiment was started when the plants had about 6 leaves after three weeks.

\section{Soil Water Contents and Soil Water Potential}

Water contents of the soil were determined by the weight difference between fresh and air-dried. Water potential of the soil was measured using Mini Tensiometer (Skye Instruments Ltd., Llandrindod Wells, UK), and data was collected every day.

\section{Plant Growth and Dimensional Parameters of Leaves}

At each harvest (day 7 and day 12), the fresh matter of leaves was weighted, and stem length and total leaves number of plant were determined.

\section{The relative water contents}

The relative water contents (RWC) was determined as follows:

$$
\text { RWC }(\%)=(F W-D W) /(T W-D W) \times 100,
$$

$\mathrm{FW}=$ fresh weight, $\mathrm{DW}=$ dry weight , and TW $=$ turgid weight. Dry weight of leaves was measured after 3 days dried in the oven at $80^{\circ} \mathrm{C}$, and a turgid weight of leaves was measured after infiltrating the samples for $12 \mathrm{~h}$ in distilled water at $4^{\circ} \mathrm{C}$ (Cameron et al. 1999). Relative growth rate (RGR, per day) of leaves was determined as: 


$$
\mathrm{RGR}=\left(\ln \mathrm{DW}_{2}-\ln \mathrm{DW}_{1}\right) /\left(\mathrm{d}_{2}-\mathrm{d}_{1}\right)
$$

where $\mathrm{DW}_{2}$ and $\mathrm{DW}_{1}$ are the dry weight of plants for two successive harvest dates $\left(\mathrm{d}_{1}\right.$ and $\left.\mathrm{d}_{2}\right)$.

\section{Stomatal Density (SD), Photosynthesis and Chlo- rophyll Fluorescence}

SD, photosynthesis and chlorophyll fluorescence of leaves were measured on day 7 and day 12 after drought treatment with three replicates. The area of four expanded leaves was calculated using the image-analyzing program (SCIONIMAGE). Stomatal density (SD) was measured on adaxial leaf surface. Stomata were counted in optical Axioskop 2 plusmicroscope (Carl Zeiss, Oberkohen, Germany) and photographs of epidermal prints (Boccalandro et al. 2007) were obtained at $\times 200$ magnification from middle portions of leaflet laminas. To determine stomatal density, further analyses were used.

Stomatal density $(\mathrm{SD})=$ no. of stomata per leaf area $\left(\mathrm{mm}^{2}\right)$

Photosynthesis was measured by a LCi portable infrared gas analyzer (IRGA) (ADC BioScientific Ltd., Hoddesdon, UK). Chlorophyll fluorescence was measured with a portable Handy PEA (Hansatech Instruments Ltd., King's Lynn, UK). Chlorophyll fluorescence was measured on the adaxial leaf surface, which had been pre-darkened for at least for $30 \mathrm{~min}$. Measurements were conducted on cloudless days and were done between 10:00 and 14:00.

\section{Contents of Chlorophyll a, Chlorophyll b and Carotenoid}

The leaf samples for chlorophyll and carotenoid contents were extracted by DMSO (Dimethyl sulfoxide) at $60^{\circ} \mathrm{C}$ for $12 \mathrm{~h}$. The contents of chlorophyll a, chlorophyll $\mathrm{b}$ and carotenoid were estimated from absorbance at 645 $\mathrm{nm}, 663 \mathrm{~nm}$ and $480 \mathrm{~nm}$ with UV mini-1240 spectrophotometer (Shimadzu, Kyoto, Japan). Quantitative estimation of the chlorophyll and carotenoid contents was obtained by using the equation of Holden (1965) and Kirk and Allen (1965), respectively.

\section{Contents of Total Ion and Osmolality}

The freeze-dried leaves were ground to a homogenous powder and extracted with boiling distilled water for $1 \mathrm{~h}$. Total ion contents (calculated as $\mathrm{NaCl}$ equivalents) were determined using a conductivity instrument (Mettler
Check Mate 90; Mettler Toledo, Columbus, OH, USA), and the osmolality of leaf extract solutions was measured by means of cryoscopy (OSMETTE micro-osmometer, model 5004; Precision Systems Inc., Natick, MA, USA).

\section{Contents of Soluble Carbohydrate and Free Proline}

Soluble carbohydrate contents of leaves were determined by using the Phenol-Sulfuric acid method. Mix leaf extract of $20 \mu \mathrm{L}$ and distilled water of $780 \mu \mathrm{L}$ and mix them with $400 \mu \mathrm{L}$ of $5 \%$ phenol solution and then put concentrated sulfuric acid $\left(98 \% \mathrm{H}_{2} \mathrm{SO}_{4}\right)$ of $2 \mathrm{~mL}$. Leave the reaction solutions undisturbed for $10 \mathrm{~min}$ and then shaking for mix. After $30 \mathrm{~min}$, the samples were measured at 490 $\mathrm{nm}$. Soluble carbohydrate was calculated from a standard curve using D-glucose.

Free proline contents were estimated following the method of Bates et al. (1973). Freeze-dried leaves (0.5 g) were extracted in 3\% sulphosalicylic acid and the homogenate filtered through filter paper. Filtrate of $2 \mathrm{~mL}$ was reacted with $2 \mathrm{~mL}$ of acid ninhydrin reagent and glacial acetic acid of $2 \mathrm{~mL}$ in a test tube for $1 \mathrm{~h}$ at $100^{\circ} \mathrm{C}$, and the reaction terminated in an ice bath. The reaction mixture was extracted with $4 \mathrm{~mL}$ of toluene and mixed vigorously with a vortex mixture for $15-20 \mathrm{~s}$. The chromophore containing toluene was aspirated from the aqueous phase, warmed to room temperature and the absorbance measured at $510 \mathrm{~nm}$ using toluene as blank. Proline concentration was calculated from a standard curve using L-proline.

\section{Statistical Analysis}

Statistical analysis of control and drought treatments at each sampling day was conducted using independent samples $t$-test. This test was carried out to determine if significant differences $(P<0.05)$ were found between two groups by using SPSS ver. 18.0 for Windows (SPSS Inc., Chicago, IL, USA). The results are shown as the mean \pm SD of three replicates.

\section{RESULTS and DISCUSSION}

\section{Soil Water Contents and Soil Water Potential}

Soil water contents were drastically reduced by water stress and the reduction of soil water contents was $89.9 \%$ and $96.0 \%$ on day 7 and day 12, respectively, in drought 

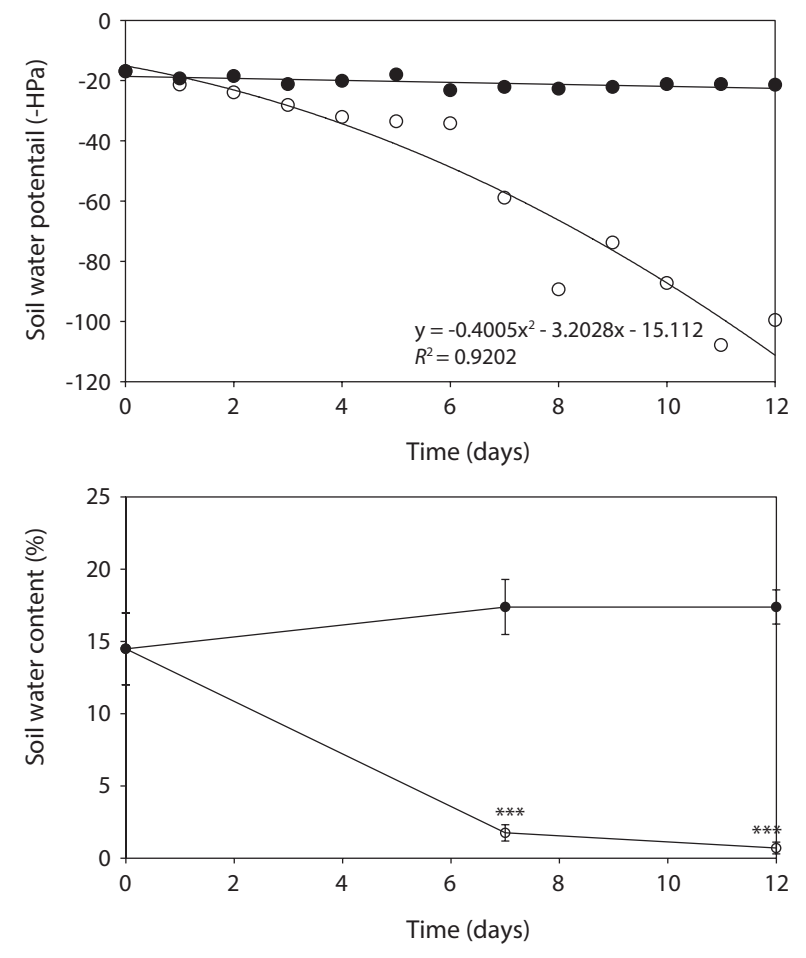

Fig. 1. Change in soil water contents and water potential in pots with well-watered $(\bullet)$ and drought treatments $(\circ)$. Means values of three replicates with standard deviation (tested with $t$-test; $P=0.05$ ). ${ }^{* * *} P<0.001$.

condition as compared to the well-watered (control) condition. During study period, soil water potential decreased continuously by water deficit in drought treatment. Determination of the soil water matric potential $(\Psi \mathrm{m})$ is significant to characterize and monitor processes such as crop yield production and plant growth (Young and Sisson 2002). During water deficit soil water potential would be decrease and this would negatively affect to water uptake (Loreto et al. 2003). Tensiometer used in this experiment is extensively used instrument for determination of $\Psi_{\mathrm{m}}$ (Or 2001, Young and Sisson 2002). In the present study, $\Psi_{\mathrm{m}}$ was consistently reduced with the decrease of soil water contents during drought period (Fig. 1), which inevitably interfere plant growth and development.

\section{Plant Growth and Dimensional Parameters of Leaves}

DW, RGR and RWC in leaves of drought treatment were lower than control after day 7, but were not shown significant difference between control and treatment (Fig. 2). A significant decrease in DW, RGR and RWC was observed on day 12 after treatment, and decreased by $64.5 \%$, $89.1 \%$ and $25.3 \%$ as compared with that in the control,
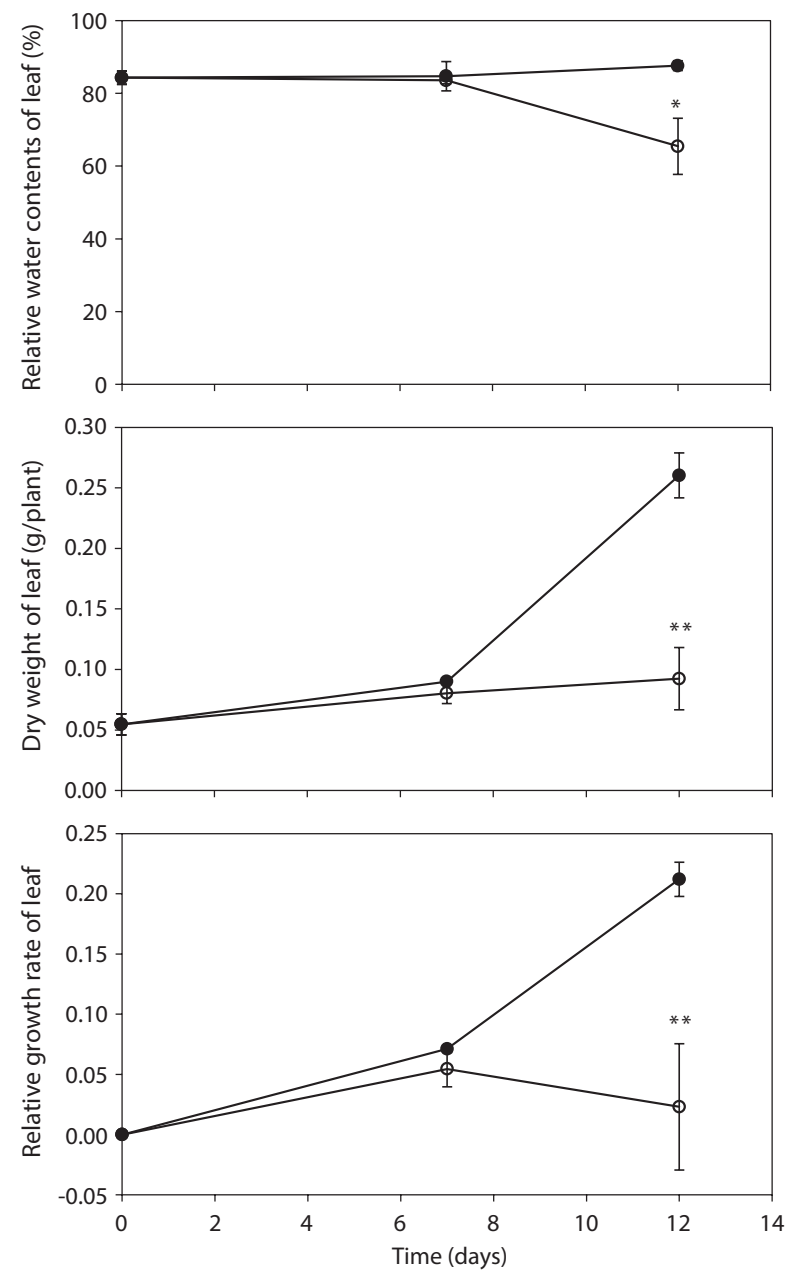

Fig. 2. Change in relative water contents, dry weight and relative growth rate of leaves per plant with well-watered $(\bullet)$ and drought treatments $(\circ)$. Means values of three replicates with standard deviation (tested with $t$-test; $P=0.05)$. ${ }^{*} P<0.05,{ }^{* *} P<0.01$.

respectively. After day 12, stem length and leaf numbers per plant in drought treatment were shorter and fewer than control, and decreased by $34.9 \%$ and $29.5 \%$ as compared to control, respectively (Fig. 3). In drought-stressed plants, RGR and RWC were not shown a significant difference compared with that of control until day 7 , but it decreased after day 12. Plant growth inhibition was observed during water deficit. In general, water deficit stress mostly reduced plant growth and development (Thakur and Kaur 2001). According to many studies, stem length was decreased under drought stress (Patel and Golakia 1988, Pita and Pardes 2001), and the reduction in plant dry weight and height is associated with the decrease of stem length (Martiniello and Ciola 1995, Iannucci and Martiniello 1998).

The differences in the leaf area of fully expanded new 

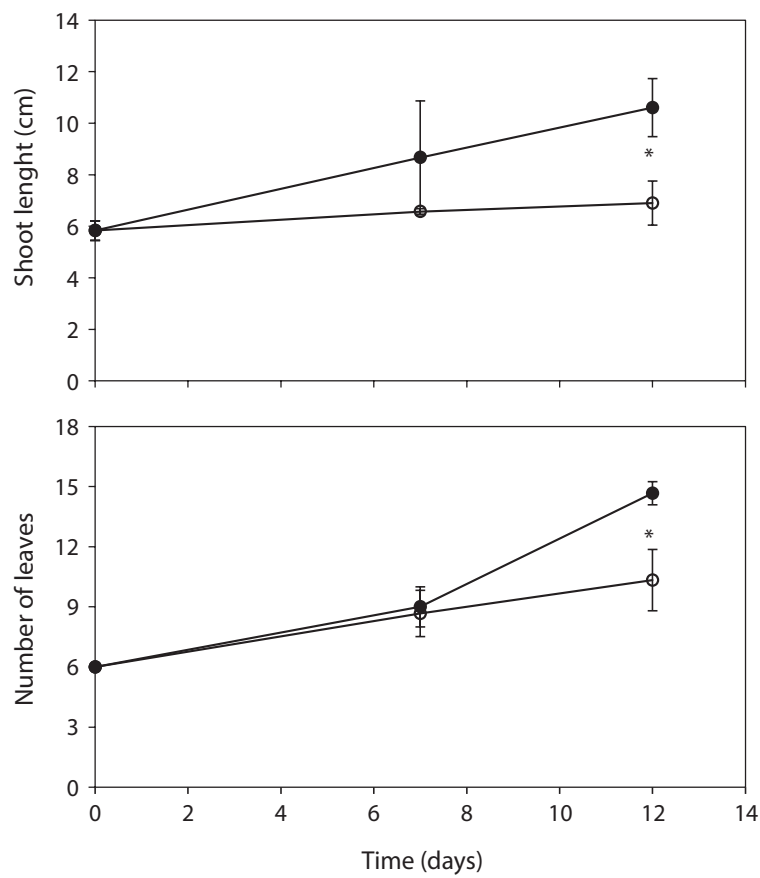

Fig. 3. Change in stem length and number of leaves per plant with wellwatered $(\bullet)$ and drought treatments $(\circ)$. Means values of three replicates with standard deviation (tested with $t$-test; $P=0.05$ ). ${ }^{*} P<0.05$.

leaves between control and drought treatment was not shown on day 7 . However, the leaf area on 12 days after drought treatment decreased by $52.2 \%$ compared with the control (Fig. 4). In the present study, water deficit stress reduced plant growth such as stem length, number of leaves and leaf area. The reduction in plant growth by water deficit is associated with the reduction of plant biomass and RGR. Leaf area plasticity is an important means by which a drought-stressed crop maintains control of water use and the leaf growth was used as a physiological trait to estimate acclimation to water deficit (Rucker et al. 1995, Blum 1996, Shubhra et al. 2003). The maintenance of higher RWC can be used as an indicator of drought resistance mechanisms in plants under soil drying conditions (Chylinski et al. 2007). Also, decrease in RWC reflects a loss of turgor causing of limited water availability (Ndayiragije and Lutts 2006).

\section{Stomata Density, Photosynthesis and Chloro- phyll Fluorescence}

On day 7 and day 12, Stomata density was not significantly different compared with that of control (Fig. 5). Stomata aparture and stomatal density mainly control the stomatal conductance of $\mathrm{CO}_{2}$ which vary with changes of


Fig. 4. Change in dimensional parameters of four expanded leaves with well-watered $(\bullet)$ and drought treatments $(\circ)$. Means values of three replicates with standard deviation (tested with $t$-test; $P=0.05$ ). ${ }^{*} P<0.05$.

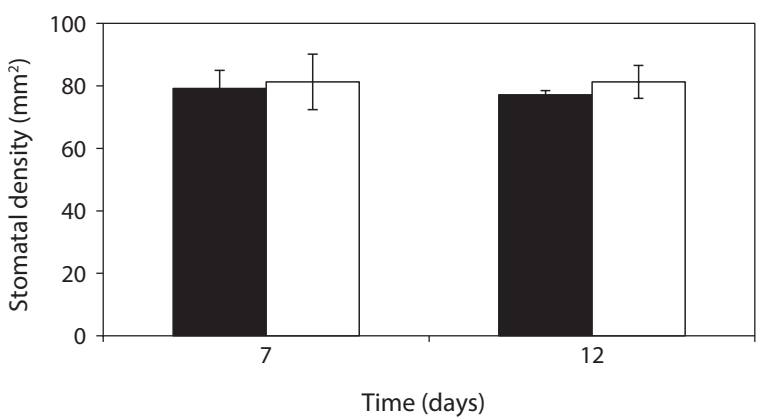

Fig. 5. The difference in stomatal density between two conditions on day 7 and day 12 with well-watered ( $\square$ ) and drought treatments ( $\square$ ). Means values of three replicates with standard deviation (tested with $t$-test; $P=0.05$ ).

leaf area in response to water availability and other environmental factors (Casson and Gray 2008, Boccalandro et al. 2009). Under stress conditions many plants increased stomatal density with the decrease of leaf area that enhanced gas exchange per leaf area and biomass yield 

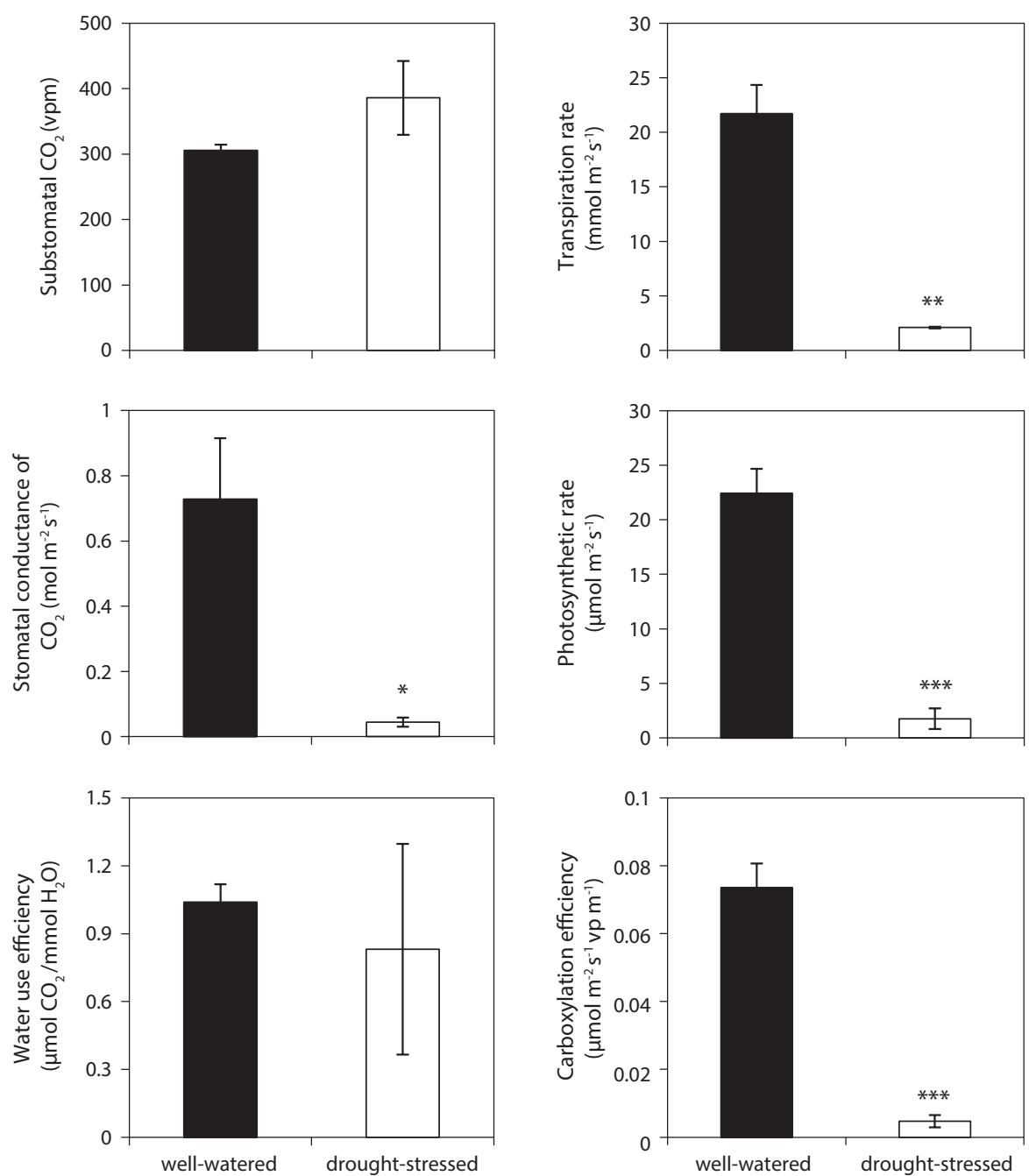

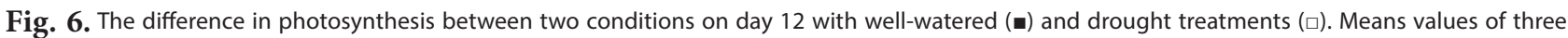
replicates with standard deviation (tested with $t$-test; $P=0.05$ ). ${ }^{*} P<0.05,{ }^{* * *} P<0.01,{ }^{* * * *} P<0.001$.

production (Yang and Wang 2001, Zhang et al. 2006, Giordano et al. 2011) whereas the number of stomata per leaf decreases (Quarrie and Jones 1977). For the stomatal density per leaf area, C. soldanella did not show significant difference between control and treatment. It is suggested that the stomatal density of $C$. soldanella is no largely affected by drought stress.

Photosynthesis was measured at the end of the final stress periods, day 12. Understanding the physiological mechanisms of many stressors is crucial to anticipating how physiological interruption will affect future plant developments. The well-watered plants showed higher net photosynthetic rate, transpiration rate, stomatal conductance of $\mathrm{CO}_{2}$, and carboxylation efficiency than those of drought-stressed plants (Fig. 6). However, there was no significant difference to the value of substomatal $\mathrm{CO}_{2}$ and water use efficiency between treatments on day 12 after drought stress. In the present study, C. soldanella showed decrease in photosynthetic rate and stomatal conductance of $\mathrm{CO}_{2}$ to a similar degree, indicating that photosynthetic rate is largely reduced due to the reduction in stomatal conductance of $\mathrm{CO}_{2}$ which is highly sensitive to soil-water deficit. Stomatal closure inhibited leaf photosynthetic capacity in drought stressed plants. According to many studies, stomatal conductance of $\mathrm{CO}_{2}$ declined before leaf water contents are influenced, and photosynthetic rate was mostly dependent on stomatal aperture (Farquhar et al. 1989, Cornic and Briantais 1991). As well as the decline in photosynthetic rate and stomatal conductice of $\mathrm{CO}_{2}$, the value of the transpiration rate was lower in drought-stressed plants than that of control. Under stressed conditions transpiration rate is largely correlated 
with stomatal conductance of $\mathrm{CO}_{2}$ according to a higher adaptability of stomata (Gratani and Ghia 2002, Niu et al. 2006). Abscisic acid (ABA), a plant stress hormone, induces the closure of leaf stomata, thereby reducing water loss through transpiration, and decreasing the rate of photosynthesis. These responses improve the water-use efficiency of the plant (Waseem et al. 2011). The water use efficiency by stomatal regulation is an imperative feature for plant species to survive in coastal sand dunes.

Maximum quantum use efficiency $\left(\mathrm{F}_{\mathrm{v}} / \mathrm{F}_{\mathrm{m}}\right)$ in darkadapted leaves corresponds to the ratio $\left(\mathrm{F}_{\mathrm{m}}-\mathrm{F}_{0}\right) / \mathrm{F}_{\mathrm{m}}$, where $\mathrm{F}_{\mathrm{m}}$ is the maximal fluorescence yield of a dark-adapted sample, with all PSII reaction centres fully closed, and $\mathrm{F}_{0}$ is the minimum fluorescence yield of a dark-adapted sample, with all PSII reaction centres fully open. $F_{v} /$ $F_{m}$ has been commonly used to identify changes in the photosynthetic apparatus as a result of stress (Baker and Rosenqvist 2004, Resco et al. 2008). Previous studies suggest that chlorophyll fluorescence parameters tend to be strongly correlated with plants mortality to react environmental stresses (Wakrim et al. 2005).

In the present study, $\mathrm{F}_{\mathrm{v}} / \mathrm{F}_{\mathrm{m}}$ were not significantly different under well-watered and drought conditions (Table 1). According to other previous studies, some plants did not show any remarkable change of $F_{v} / F_{m}$ under drought stress whereas plant growth was rapidly decreased (Munns et al. 2010). C. soldanella photochemical activity

Table 1. Change in chlorophyll fluorescence parameters $\left(F_{0}, F_{m}\right.$ and $F_{v} /$ $F_{m}$ ) with well-watered and drought treatments

\begin{tabular}{lccccc}
\hline & \multicolumn{2}{c}{ Day 7} & & \multicolumn{2}{c}{ Day 12} \\
\cline { 2 - 3 } \cline { 5 - 5 } \cline { 5 - 5 } & well-watered & drought & & well-watered & drought \\
\hline $\mathrm{F}_{0}$ & $341 \pm 10.6$ & $386 \pm 55.8$ & & $350 \pm 36.9$ & $435 \pm 87.9$ \\
$\mathrm{~F}_{\mathrm{m}}$ & $1614 \pm 124$ & $1438 \pm 112$ & & $1461 \pm 124$ & $1483 \pm 95$ \\
$\mathrm{~F}_{\mathrm{v}} / \mathrm{F}_{\mathrm{m}}$ & $0.79 \pm 0.02$ & $0.73 \pm 0.05$ & & $0.76 \pm 0.02$ & $0.71 \pm 0.05$ \\
\hline
\end{tabular}

$F_{0}, F_{m}$ and $F_{v} / F_{m}$ mean the minimum fluorescence intensity, the maximal fluorescence intensity and the maximum quantum efficiency of PSII photochemistry, respectively. Means values of three replicates with standard deviation (tested with $t$-test; $P=0.05$ ). was resistant to water stress and the electron transport chain was maintained under water deficit conditions, even though photosynthetic rate and stomatal conductice of $\mathrm{CO}_{2}$ were strongly limited.

\section{Contents of Chlorophyll a, Chlorophyll b and Carotenoid}

On day 7, chlorophyll a, total chlorophyll and carotenoid contents showed small increase $15.7 \%, 15.5 \%$ and $16.3 \%$, respectively, in drought treatment as compared to the control. On day 12, chlorophyll b, total chlorophyll and carotenoid contents of the stressed plants were lower than those of controls, but there were no significantly different (Table 2).

Water stress leads to a decline in photosynthetic activity and change of the chloroplast capacity (Martinez et al. 2003, Jaleel et al. 2007, Massacci et al. 2008). Decrease of chlorophylls and carotenoid contents by stressed conditions was reported in several plant species (Loggini et al. 1999, Agastian et al. 2000). In the present study, contents of chlorophyll and carotenoid under water stress were decreased after 12 days, but there was no significant difference compared to control. It is suggested that the capacity of chloroplast does not get much damage from drought conditions.

\section{Contents of Total Ion, Osmolality, Soluble Carbo- hydrate and Proline}

The total ion contents and osmolality of droughtstressed plants had higher than control plants during study period. The value of total ion contents and osmolality gradually increased and it is significantly different than those of control. Total ion contents in the leaf of droughtstressed plant were increased by $19.7 \%$ and $36.3 \%$, and osmolality was increased by $41.5 \%$ and $32.3 \%$ as compared to control on the day 7 and day 12 , respectively.

Soluble carbohydrate contents were gradually increased during drought stress. The value of the soluble

Table 2. Change in chlorophyll and carotenoid contents with well-watered and drought treatments

\begin{tabular}{lcccccc}
\hline & \multicolumn{3}{c}{ Day 7} & & \multicolumn{2}{c}{ Day 12 } \\
\cline { 2 - 3 } \cline { 5 - 6 } & well-watered & drought & & well-watered & drought \\
\hline Chla $(\mathrm{mg} / \mathrm{g})$ & $6.82 \pm 0.30$ & $7.89 \pm 0.30^{*}$ & & $6.42 \pm 0.29$ & $6.50 \pm 1.26$ \\
Chlb (mg/g) & $1.41 \pm 0.01$ & & $1.61 \pm 0.21$ & & $1.20 \pm 0.27$ & $0.68 \pm 0.43$ \\
Total Chl (mg/g) & $8.23 \pm 0.32$ & $9.50 \pm 0.19^{* *}$ & & $7.62 \pm 0.55$ & $7.18 \pm 0.92$ \\
Carotenoid (mg/g) & $416 \pm 13.62$ & $483 \pm 10.31^{* *}$ & & $408 \pm 19.85$ & $375 \pm 48.41$ \\
\hline
\end{tabular}

${ }^{*} P<0.05,{ }^{* *} P<0.01$. Means values of three replicates with standard deviation (tested with $t$-test; $P=0.05$ ). 
Table 3. Change in total ion, osmolality, soluble carbohydrate and free proline contents

\begin{tabular}{|c|c|c|c|c|}
\hline \multirow{2}{*}{ Day } & \multicolumn{2}{|c|}{ Ion contents ( $\mu \mathrm{eq} / \mathrm{g}$ plant water) } & \multicolumn{2}{|c|}{ Osmolality ( $\mu$ osm/g plant water) } \\
\hline & well-watered & drought & well-watered & drought \\
\hline 0 & \multicolumn{2}{|c|}{$262 \pm 0.69$} & \multicolumn{2}{|c|}{$275 \pm 1.23$} \\
\hline 7 & $233 \pm 16.34$ & $279 \pm 9.87^{*}$ & $235 \pm 8.65$ & $333 \pm 11.90^{* * *}$ \\
\hline 12 & $240 \pm 25.27$ & $327 \pm 3.22^{*}$ & $291 \pm 29.18$ & $386 \pm 23.68^{*}$ \\
\hline \multirow{2}{*}{ Day } & \multicolumn{2}{|c|}{ Carbohydrate ( $\mu$ mole/g plant water) } & \multicolumn{2}{|c|}{ Proline ( $\mu$ mole/g leaf weight) } \\
\hline & well-watered & drought & well-watered & drought \\
\hline 0 & \multicolumn{2}{|c|}{$14.27 \pm 6.71$} & \multicolumn{2}{|c|}{$0.83 \pm 0.37$} \\
\hline 7 & $21.17 \pm 5.91$ & $18.35 \pm 0.47$ & $0.83 \pm 0.30$ & $1.88 \pm 0.47^{*}$ \\
\hline 12 & $30.26 \pm 3.22$ & $24.83 \pm 1.12$ & $0.47 \pm 0.44$ & $8.75 \pm 1.53^{* *}$ \\
\hline
\end{tabular}

carbohydrate contents was similar between control and treatment. Control was litter higher than drought treatment, but it is no significant difference. Proline synthesis was greatly enhanced in drought-stressed plants (Table 3). Proline contents in the drought-stressed plants on the day 7 and day 12 were 2.27 and 18.6 times greater than those of controls. It is indicated that the increase of osmolality in stressed plants was due to the accumulation of osmolytes by water deficit. To prevent water loss, drought-stressed plants try to promote with an increase in osmolality (Chaves et al. 2003). Plant capacity for osmotic adjustment could be important to maintain water absorption in sand dune plant species under water deficit (Nilsen et al. 1984). For these reasons, plants accumulate other compatible solutes such as sugar, glycerol, betaines, proline and inorganic ions under water stress conditions (Bray 1997, Hare et al. 1998, Chaves et al. 2003), and also degree of proline accumulation correlates with the change of water potential and RWC (Knipp and Honermeier 2006).

In the present study, total ion contents and osmolality are higher than those of control, and which are continuously increased with water stress. Also, increase of proline contents in leaves induced by drought stress agreed with previous studies, and accumulation of proline is one of the general adaptive mechanisms in many plants (Hare et al. 1998, Abdel-Nasser and Abdel-Aal 2002). However, soluble carbohydrate did not show any remarkable difference compared to control plants. It may be C. soldanella use other ions as compatible solutes rather than soluble carbohydrates. In order to enhance water uptake and prevent water loss, C. soldanella accumulate ions and particularly proline to tolerate and survive on sand dune conditions of drought.
In conclusion, physiological responses of C. soldanella to water-deficit were related to the drought duration. After day 7 of drought treatment, the inhibition of plant growth and the maximum efficiency of photosystem II (PSII) photochemistry $\left(\mathrm{F}_{\mathrm{v}} / \mathrm{F}_{\mathrm{m}}\right)$ was not observed, but the contents of total ion and proline increased, indicating that the accumulation of ion and osmotic solutes in C. soldanella may help to maintain plant growth under the water stress condition. The photosynthetic rate and stomatal conductance in drought stressed C. soldanella plant for 12 days were decreased by $92.2 \%$ and $93.9 \%$, respectively, with a low leaf RWC of $25.3 \%$, but $\mathrm{F}_{\mathrm{v}} / \mathrm{F}_{\mathrm{m}}$ was not affected under drought condition, indicating the photosynthesis down regulation may mainly derive from stomatal limitation for this species. The water use efficiency by stomatal regulation is an imperative feature for plant species to survive in coastal sand dunes. The increase of solute, mainly ion and proline indicated that C. soldanella plant under severe drought condition is the responses to overcome low osmotic potential of soil.

\section{ACKNOLEDGMENTS}

This work was supported by the Eco-Innovation project and Long Term Ecological Research (LTER) of the Ministry of Environment, Korea.

\section{LITERATRUE CITED}

Abdel-Nasser LE, Abdel-Aal AE. 2002. Effect of elevated $\mathrm{CO}_{2}$ and drought on proline metabolism and growth of safflower (Carthamus mareoticus L.) seedlings without im- 
proving water status. Pak J Biol Sci 5: 523-528.

Acevedo E, Theodore CH, Henderson DW. 1971. Immediate and subsequent growth responses of maize leaves to changes in water status. Plant Physiol 48: 631-636.

Agastian P, Kingsley SJ, Vivekanandan M. 2000. Effect of salinity on photosynthesis and biochemical characteristics in mulberry genotypes. Photosynthetica 38: 287290.

Angelopoulos K, Dichio B, Xiloyannis C. 1996. Inhibition of photosynthesis in olive trees (Olea europaea L.) during water stress and rewatering. J Exp Bot 47: 1093-1100.

Baher ZF, Mirza M, Ghorbanli M, Rezaii MB. 2002. The influence of water stress on plant height, herbal and essential oil yield and composition in Satureja hortensis L. Flavour Frag J 17: 275-277.

Baker NR, Rosenqvist E. 2004. Applications of chlorophyll fluorescence can improve crop production strategies: an examination of future possibilities. J Exp Bot 55: 1607-1621.

Bartels D, Sunkar R. 2005. Drought and salt tolerance in plants. Crit Rev Plant Sci 24: 23-58.

Bates LS, Waldren RP, Teare ID. 1973. Rapid determination of free proline for water-stress studies. Plant Soil 39: 205-207.

Bhatt RM, Srinivasa Rao NK. 2005. Influence of pod load on response of okra to water stress. Indian J Plant Physi 10: 54-59.

Blum A. 1996. Crop responses to drought and the interpretation of adaptation. Plant Growth Regul 20: 135-148.

Boccalandro H, Casal J, Serna L. 2007. Secret message at the plant surface. Plant Signal Behav 2: 373-375.

Boccalandro HE, Rugnone ML, Moreno JE, Ploschuk EL, Serna L, Yanovsky MJ, Casal JJ. 2009. Phytochrome B enhances photosynthesis at the expense of water-use efficiency in Arabidopsis. Plant Physiol 150: 1083-1092.

Bray EA. 1997. Plant responses to water deficit. Trends Plant Sci 2: 48-54.

Cameron RWF, Harrison-Murray RS, Scott MA. 1999. The use of controlled water stress to manipulate growth of container-grown Rhododendron cv. Hoppy. J Hortic Sci Biotech 74: 161-169.

Casson S, Gray JE. 2008. Influence of environmental factors on stomatal development. New Phytol 178: 9-23.

Chaves MM, Maroco JP, Pereira JS. 2003. Understanding plant responses to drought-from genes to the whole plant. Funct Plant Biol 30: 239-264.

Chylinski WK, Lukaszewska AJ, Kutnik K. 2007. Drought response of two bedding plants. Acta Physiol Plant 29: 399-406.

Clifton-Brown JC, Lewandowski I, Bangerth F, Jones MB.
2002. Comparative responses to water stress in staygreen, rapid-and slow senescing genotypes of the biomass crop, Miscanthus. New Phytol 154: 335-345.

Cornic G, Briantais JM. 1991. Partitioning of photosynthetic electron flow between $\mathrm{CO}_{2}$ and $\mathrm{O}_{2}$ reduction in a C3 leaf (Phaseolus vulgaris L.) at different $\mathrm{CO}_{2}$ concentration and during drought stress. Planta 183: 178-184.

De Ronde JA, Van Der Mescht A, Steyn HSF. 2000. Proline accumulation in response to drought and heat stress in cotton. Afr Crop Sci J 8: 85-92.

Farooq M, Wahid A, Kobayashi N, Fujita D, Basra SMA. 2009. Plant drought stress: effects, mechanisms and management. Agron Sustain Dev 29: 185-212.

Farquhar GD, Wong SC, Evans JR, Hubick KT. 1989. Photosynthesis and gas exchange. In: Plants under Stress, Society for Experimental Biology Semina Series 39 (Jones HG, Flowers TJ, Jones MB, eds). Cambridge University Press, Cambridge, pp 47-69.

Flexas J, Escalona JM, Medrano H. 1998. Down-regulation of photosynthesis by drought under field conditions in grapevine leaves. Aust J Plant Physiol 25: 893-900.

Giordano CV, Guevara A, Boccalandro HE, Sartor C, Villagra PE. 2011. Water status, drought responses, and growth of Prosopis flexuosa trees with different access to the water table in a warm South American desert. Plant Ecol 212: 1123-1134.

Gratani L, Ghia E. 2002. Changes in morphological and physiological traits during leaf expansion of Arbutus unedo. Environ Exp Bot 48: 51-60.

Hare PD, Cress WA, Van Staden J. 1998. Dissecting the roles of osmolyte accumulation during stress. Plant Cell Environ 21: 535-553.

Hesp PA. 1991. Ecological processes and plant adaptations on coastal dunes. J Arid Environ 21: 165-191.

Holden M. 1965. Chlorophylls. In: Chemistry and biochemistry of plant pigments (Goodwin TW, ed). Academic Press, London \& New York, pp 461-488.

Iannucci A, Martiniello P. 1998. Analysis of seed yield and yield components in four Mediterranean annual clovers. Field Crop Res 55: 235-243.

Jaleel CA, Gopi R, Sankar B, Manivannan P, Kishorekumar A, Sridharan R, Panneerselvam R. 2007. Alterations in germination, seedling vigour lipid peroxidation and proline metabolism in Catharanthus roseus seedlings under salt stress. S Afr J Bot 73: 190-195.

Karthikeyan B, Jaleel CA, Gopi R, Deiveekasundaram M. 2007. Alterations in seedling vigour and antioxidant enzyme activities in Catharanthus roseus under seed priming with native diazotrophs. J Zhejiang Univ Sci B 8: 453-457. 
Kirk JT, Allen RL. 1965. Dependence of chloroplast pigment synthesis on protein synthesis: effect of actidione. Biochem Biophys Res Commun 21: 523-530.

Knipp G, Honermeier B. 2006. Effect of water stress on proline accumulation of genetically modified potatoes ( $\mathrm{So}$ lanum tuberosum L.) generating fructans. J Plant Physiol 163: 392-397.

Kumar A, Singh DP. 1998. Use of physiological indices as a screening technique for drought tolerance in oilseed Brassica species. Ann Bot 81: 413-420.

Lawlor DW, Cornic G. 2002. Photosynthetic carbon assimilation and associated metabolism in relation to water deficits in higher plants. Plant Cell Environ 25: 275-294.

Loggini B, Scartazza A, Brugnoli E, Navari-Izzo F. 1999. Antioxidative defense system, pigment composition, and photosynthetic efficiency in two wheat cultivars subjected to drought. Plant Physiol 119: 1091-1099.

Loreto F, Centritto M, Chartzoulakis K. 2003. Photosynthetic limitations in olive cultivars with different sensitivity to salt stress. Plant Cell Environ 26: 595-601.

Lu CM, Zhang JH. 1998. Effects of water stress on photosynthesis, chlorophyll fluorescence and photoinhibition in wheat plants. Aust J Plant physiol 25: 883-892.

Martinez JP, Ledent JF, Bajji M, Kinet JM, Lutts S. 2003. Effect of water stress on growth, $\mathrm{Na}^{+}$and $\mathrm{K}^{+}$accumulation and water use efficiency in relation to osmotic adjustment in two population of Atriplex halimus L. Plant Growth Regul 41: 63-73.

Martiniello P, Ciola A. 1995. Dry matter and seed yield of Mediterranean annual legume species. Agron J 87: 985993.

Massacci A, Nabiev SM, Pietrosanti L, Nematov SK, Chernikova TN, Thor K, Leipner J. 2008. Response of the photosynthetic apparatus of cotton (Gossypium hirsutum) to the onset of drought stress under field conditions studied by gas-exchange analysis and chlorophyll fluorescence imaging. Plant Physiol Biochem 46: 189195.

Maun MA. 1998. Adaptations of plants to burial in coastal sand dunes. Can J Botany 76: 713-738.

Monson Rk, Littlejohn RO, Williams JG. 1983. Photosynthetic adaptation to temperature in four species from the Colorado Shortgrass steppe: a physiological model for coexistence. Oecologia 58: 43-51.

Mooney HA, Field C, Vazquez-Yanes C, Chu C. 1983. Environmental controls on stomatal conductance in a shrub of the humid tropics. Proc Natl Acad Sci USA 80: 12951297.

Munns R. 2002. Comparative physiology of salt and water stress. Plant Cell Environ 25: 239-250.
Munns R, James RA, Sirault XRR, Furbank RT, Jones HG. 2010. New phenotyping methods for screening wheat and barley for beneficial responses to water deficit. J Exp Bot 61: 3499-3507.

Ndayiragije A, Lutts S. 2006. Do exogenous polyamines have an impact on the response of a salt-sensitive rice cultivar to $\mathrm{NaCl}$ ? J Plant Physiol 163: 506-516.

Nilsen ET, Sharifi MR, Rundel PW. 1984. Comparative water relations of phreatophytes in the Sonoran desert of California. Ecology 65: 767-778.

Niu SL, Jiang GM, Wan SQ, Li YG, Gao L, Liu M. 2006. A sandfixing pioneer $\mathrm{C} 3$ species in sandland displays characteristics of C4 metabolism. Environ Exp Bot 57: 123-130.

Or D. 2001. Who invented the tensiometer? Soil Sci Soc Am J 65: 1-3.

Parida A, Das AB, Das P. 2002. NaCl stress causes changes in photosynthetic pigments, proteins and other metabolic components in the leaves of a true mangrove, Bruguiera parviflora, in hydroponic cultures. J Plant Biol 45: 28-36.

Paseban-Islam B, Shakiba MR, Neyshabouri MR, Moghaddam M, Ahmadi MR. 2000. Evaluation of physiological indices as a screening technique for drought resistance in oilseed rape. Proc Pakistan Acad Sci 37: 143-152.

Patel MS, Golakia BA. 1988. Effect of water stress on yield attributes and yield of groundnut (Arachis hypogaea L.). Indian J Agr Sci 58: 701-703.

Pita P, Pardos JA. 2001. Growth, leaf morphology, water use and tissue water relation of Eucalyptus globulus clones in reponse to water deficit. Tree physiol 21: 599-607.

Quarrie SA, Jones HG. 1977. Effects of abscisic acid and water stress on development and morphology of wheat. J Exp Bot 28: 192-203.

Resco V, Ignace DD, Sun W, Huxman TE, Weltzin JF, Williams DG. 2008. Chlorophyll fluorescence, predawn water potential and photosynthesis in precipitation pulsedriven ecosystems - implications for ecological studies. Funct Ecol 22: 479-483.

Rucker KS, Kvien CK, Holbrook CC, Hook JE. 1995. Identification of peanut genotypes with improved drought avoidance traits. Peanut Sci 22: 14-18.

Shao HB, Chu LY, Lu ZH, Kang CM. 2008. Primary antioxidant free radical scavenging and redox signaling pathways in higher plant cells. Int J Biol Sci 4: 8-14.

Shubhra V, Dayal J, Goswami CL. 2003. Effect of phosphorus application on growth, chlorophyll and proline under water deficit in clusterbean (Cyamopsis tetragonoloba $\mathrm{L}$. Taub). Indian J Plant Physi 8: 150-154.

Silva MA, Jifon JL, Da Silva JAG, Sharma V. 2007. Use of physiological parameters as fast tools to screen for drought tolerance in sugarcane. Braz J Plant Physiol 19: 193-201. 
Thakur PS, Kaur H. 2001. Variation in photosynthesis, transpiration, water use efficiency, light transmission and leaf area index in multipurpose agroforestry tree species. Indian J Plant Physi 6: 249-253.

Wakrim R, Wahbi S, Tahi H, Aganchich B, Serraj R. 2005. Comparative effects of partial root drying (PRD) and regulated deficit irrigation (RDI) on water relations and water use efficiency in common bean (Phaseolus vulgaris L.). Agr Ecosyst Environ 106: 275-287.

Waseem M, Ali A, Tahir M, Nadeem MA, Ayub M, Tanveer A, Ahmad R, Hussain M. 2011. Mechanism of drought tolerance in plant and its management through different methods. Continental J Agr Sci 5: 10-25.

Yang HM, Wang GX. 2001. Leaf stomatal densities and distribution in Triticum aestivum under drought and $\mathrm{CO}_{2}$ enrichment. Acta Phytoecol Sin 25: 312-316.

Young MH, Sisson JB. 2002. Tensiometry. In: Methods of Soil Analysis, Part 4: Physical Methods SSSA Book Ser. 5 (Dane JH, Topp GC, eds). Soil Science Society of America, Madison, WI, pp 575-608.

Zhang YP, Wang ZM, Wu YC, Zhang X. 2006. Stomatal characteristics of different green organs in wheat under different irrigation regimes. Acta Agronom Sin 32: 70-75. 